\title{
Optimization of Cellulase Production by Aspergillus niger ITBCC L74 with Bagasse as Substrate using Response Surface Methodology
}

\author{
Abdullah $^{1,2}$, Hamid ${ }^{1,2}$, Marcelinus Christwardana ${ }^{3 *}$, H. Hadiyanto ${ }^{1,2,3,}$ \\ ${ }^{1}$ Department of Chemical Engineering, Diponegoro University, Jln. Prof. Soedarto, SH, Tembalang, Semarang, Indonesia \\ ${ }^{2}$ Center of Biomass and Renewable Energy (C-BIORE), Department of Chemical Engineering, Diponegoro University, Jln. Prof. H. \\ Soedarto, SH, Tembalang, Semarang, Indonesia \\ ${ }^{3}$ Graduate School of Energy and Environment, Department of New Energy Engineering, Seoul National University of Science and \\ Technology, 232 Gongneung-ro, Nowon-gu, Seoul 01811, Republic of Korea \\ ${ }^{4}$ Master Program of Environmental Science, School of Postgraduate Studies, Diponegoro University, Jln. Imam Bardjo, SH No 3, \\ Semarang, Indonesia
}

\section{ARTICLE INFO}

\section{Article history:}

Received October 26, 2017

Received in revised form December 1, 2017

Accepted January 15, 2018

\section{KEYWORDS:}

Aspergillus niger,

bagasse, cellulase,

optimization,

solid state fermentation

\begin{abstract}
Cellulase is a very important enzyme for lignocelluloses based ethanol production. Bagasse contains mainly cellulose $(57.76 \%)$, hemicellulose $(12.44 \%)$, lignin $(21.34 \%)$, and others $(7.96 \%)$. Lignocellulosic material has been considered as the good option for cellulase production because it is cheap and already available in a huge amount. The objective of this research was to produce cellulase enzyme and to optimize it by using response surface methodology. The bagasse with water content of $80 \%$ was incubated with $2 \mathrm{ml}$ inoculum of Aspergillus niger ITBCC L74 in a $250 \mathrm{ml}$ Erlenmeyer flask. After reaching the specified time the enzyme was extracted and then determined for its activity. Effect of process parameters such as $\mathrm{pH}$, urea and $\mathrm{MgCl}_{2}$ addition were studied. The optimal cellulase activity was achieved at urea concentration of $4.5 \%(\mathrm{w} / \mathrm{w}), \mathrm{MgCl}_{2}$ concentration of $1 \mathrm{mM}$ and $\mathrm{pH}$ of 3.5, with maximum enzyme activity was $0.630 \mathrm{U} / \mathrm{gr}$.
\end{abstract}

\section{Introduction}

Commercial enzymes for industrial applications are mainly extracted from three main sources namely plants, animals, and microorganisms. Among three resources, microbial is more popular as enzyme sources (Abubakar and Oloyede 2013). The recent developments in bioconversion of agricultural and industrial wastes to chemical feedstock have led to extensive studies on cellulolytic enzymes produced by fungi and bacteria. Large quantities of lignocellulosic wastes are generated through forestry, agricultural practices, and industrial processes, particularly from agro-allied industries such as sugar cane, breweries, paper pulp, textile, and timber industries. These wastes generally accumulate in the environment thereby causing pollution problem. Lignocellulose is a major renewable natural resource of the world and represents a major source of renewable organic matter. The plant biomass regarded as "wastes" are biodegradable and can be converted into valuable products such as enzymes, biofuels, chemicals, cheap energy sources for fermentation, improved animal feeds and human nutrients (Acharya et al. 2008).

\footnotetext{
* Corresponding Author.

E-mail Address: marcelinus@seoultech.ac.kr
}

Lignocellulose or cellulose can be hydrolyzed become glucose, cellobiose and cello-oligosaccharides (Singhania et al. 2010). Due to that reason, cellulose or lignocellulose can be used for cellulase production via biological route utilizing bacterial or fungal (Sindhu et al. 2016). Aerobic and anaerobic bacteria, anaerobic fungi, soft rot fungi (SRF), white rot fungi (WRF), and brown rot fungi (BRF) are capable microorganisms widely used for producing cellulase (Lynd et al. 2002; Kuhad and Singh 2007; Chandel et al. 2012) which are able to produce a complete cellulase system such as endo- $\beta$-glucanase, exo- $\beta$-glucanase, and $\beta$-glucosidase (Knowles et al. 1987), compared to bacteria (Cen and Xia 1999).

Trichoderma reesei and Aspergillus niger are two strains of soft rot fungi most commonly used for commercial cellulase production via SF (Pandey et al. 2010) because of the ease of handling and greater control of environmental factors such as temperature and $\mathrm{pH}$. But, cultivation of $T$. reesei or $A$. niger by $S F$ process produced incomplete or deficiency in cellulase components although theoretically it is able to produce a complete cellulase system (Ahamed and Vermette 2008; Yoon et al. 2014). It also resulted low concentration of cellulase which can need further purification and affect to cost production (Rodriguez and Sanroman 2005). Due to the shortcomings 
mentioned, SSF can be used as one of alternative way to produce high concentration of cellulase and reduces the cost of enzyme production (Holker et al. 2004; Singhania et al. 2009). Moreover, the other advantages of SSF include superior productivity, simple technique, low capital investment, low energy requirement and less water content (Mrudula and Murugammal 2011).

Sugar industries that are located in Indonesia producing large quantity of solid waste namely bagasse (Daniyanto et al. 2015). The bagasse contains mainly cellulose (57.76\%), hemicellulose (12.94\%), lignin (21.34\%), and others (7.96\%) which is more less similar with lignocellulose contents in reference (Bahera and Ray 2016). For that reason, bagasse become a potential source for cellulase production by utilizing fungi, especially A. niger. The cellulase production using SSF by $A$. niger and $T$. reesei was carried out on bagasse with initial moisture content of $80 \%$ at $30^{\circ} \mathrm{C}$. The result shows that $A$. niger was better than $T$. reesei after 72 hours incubation with the enzyme activity of CMCase for A. niger ITBCC L74, A. niger ITBCC L161 and T. reesei UGM 6131 reached the maximum of $0.5251,0.3927$, and $0.3264 \mathrm{U} / \mathrm{g}$, respectively (Abdullah et al. 2016). In other experiment, Cunha et al. (2012) conducted cellulase production by $A$. niger by using sequential solid-state and submerged fermentation. While the behavior of $A$. niger growth on sugarcane bagasse had been reported by de Souza et al. (2011). Gottschalk et al. (2010) reported multi-enzymes production including cellulase by utilizing blend fungi between Aspergillus and Trichoderma. Amylase is also produced by SSF using $A$. niger utilizing sugarcane bagasse as source other than cellulase production, as reported by Rosés and Guerra (2009). Beside bagasse, other raw material which contain lignocellulose or cellulose can be used as substrate in cellulase production. For instance, wheat straw, orange waste, cassava waste, and banana waste have been investigated by several researchers for their potential to be used as substrates (Krishna 1999; Tabka et al. 2006; Omojasola and Jilani 2008; Olanbiwoninu and Odunfa 2016).

The response surface methodology (RSM) consists of a group of empirical techniques devoted to the evaluation of relations existing between a cluster of controlled experimental factors and are measure responses, according to one or more selected criteria. The maximum values were taken as the response of the design experiments. The optimal of the factors were obtained by solving the regression equation and also by analyzing the response surface contour plots (Sen 1997).

The first step in the experimental study of RSM is to decide a model from which expresses the response as a function on independent variable in the process. The different types of model have been used to predict the optimal response such as first and second-degree polynomial. However, many literatures have reported that by using the quadratic model, the optimal response can be obtained accurately (Murphy 1977; Vazquez and Martin 1998).

The aim of this study is to determine the optimum conditions in producing cellulase enzyme under solid state fermentation using bagasse as substrate with A. niger ITB CC L74. A statistical approach such as RMS and factorial experiment design is used to involve a minimum number of experiments for a large number of factors where these methods have also been demonstrated to improve the cellulase production. The present work describes the interaction and optimization among variables of $\mathrm{pH}$, urea concentration, and $\mathrm{MgCl}_{2}$ concentration in the culture medium which are successful to produce cellulase by $A$. niger.

\section{Materials and Methods}

\subsection{Materials}

Chemicals used for media and analysis in this study were purchased from Merck (Massachusetts, USA), Potato Dextrose Agar (PDA) was purchased from Oxoid (Hampshire, UK), while Ethanol was obtained from PT Brataco (Jakarta, Indonesia). Bagasse as substrate of fermentation process was obtained from Sugar Factory, Mojo Panggung, Tulungagung, Indonesia and was pre-treated by using $2 \% \mathrm{NaOH}$ to remove the core and noncore lignin fractions (Doran et al. 1994), then dried in an oven at $80^{\circ} \mathrm{C}$, crushed, and sieved to an average size of 40 mesh.

\subsection{Inoculum Preparation}

A. niger ITBCC L74, microorganism used in this study, was obtained from Bandung Institute of Technology and maintained at $4^{\circ} \mathrm{C}$ on Potato Dextrose Agar (PDA) slants.

\subsection{Solid State Fermentation (SSF) Procedure}

Cellulase is produced by $A$ niger in a erlenmeyer flask with bagasse as substrate. 10 grams of bagasse with water content of $80 \%$ was incubated with 2 $\mathrm{ml}$ inoculum in a $250 \mathrm{ml}$ Erlenmeyer flask. $5 \mathrm{ml}$ of nutrients were added in accordance with Mandels nutrients (Omojasola et al. 2008; Raza et al. 2011) which is consisted of: $1 \mathrm{~g}$ peptone, $1.4 \mathrm{~g}\left(\mathrm{NH}_{4}\right)_{2} \mathrm{SO}_{4}$, $2 \mathrm{~g} \mathrm{KH}_{2} \mathrm{PO}_{4}, 0.3 \mathrm{~g} \mathrm{CaCl}_{2}, 0.3 \mathrm{~g} \mathrm{MgCl}_{2} \cdot 6 \mathrm{H}_{z} \mathrm{O}, 0.3 \mathrm{~g}$ Urea, with $1 \mathrm{ml}$ of trace metal which consisted of $2.5 \mathrm{~g}$ $\mathrm{FeSO}_{4}, 0.98 \mathrm{~g} \mathrm{MnSO}_{4} \cdot \mathrm{H}_{2} \mathrm{O}, 1.76 \mathrm{~g} \mathrm{ZnSO}_{4} \cdot \mathrm{H}_{2} \mathrm{O}, 1.83 \mathrm{~g}$ $\mathrm{CoCl}_{2} \cdot 6 \mathrm{H}_{2} \mathrm{O}$ in $495 \mathrm{ml}$ De-ionized (DI) water and 5 $\mathrm{ml} \mathrm{HCl}$. The erlenmeyer flask was incubated at $35^{\circ} \mathrm{C}$ for at least 3 days (Vu et al. 2011). After reaching the specified time, the cellulase enzyme was extracted 
with a sodium citrate buffer solution $\mathrm{pH} 4.5$ with the ratio against dry bagasse was 10:1 w/v. The enzyme activity was analyzed by the Ghose method (Ghose 1987). Composition of urea and $\mathrm{MgCl}_{2}$ in the culture medium and $\mathrm{pH}$ were varied for optimization studies, while temperature and time of fermentation were fixed.

\subsection{Response Surface Methodology (RSM) Determination}

The statistical software, Minitab 17 - Trial Version (Pennsylvania, USA) was used for model equation determination and plotting the response surface while ANOVA also was used to analyze the statistical parameter as well.

\section{Results}

\subsection{Bagasse Characterization}

The treated bagasse with $2 \% \mathrm{NaOH}(\mathrm{w} / \mathrm{v})$ was analyzed for its cellulose, hemicellulose, and lignin content by Chesson-Datta method (Chesson 1981). The content of cellulose, hemicellulose, and lignin after pretreatment is $57.76 \pm 0.49 \%, 12.44 \pm 0.35 \%$, and $21.34 \pm 0.18 \%$ respectively. This is compatible with the results of research that has been done by Sarkar and Aikat (2012).

\subsection{Determination Equation Models Using RMS}

It is important to optimize the solid fermentation process by utilizing A. niger ITBCC L74 with duration of fermentation is three days and water content is $80 \%$. The levels of variables investigated in this study are given in Table 1. The central values (zero level) chosen for experimental design were: urea concentration of $3 \%(\mathrm{w} / \mathrm{w})$, magnesium chloride of $2.5 \mathrm{mM}$ and $\mathrm{pH}$ of 4.5. For three variables using Box-Behnken Design using Design Expert 6 - Trial Version (Minnesota, USA), there are 14 experiments with 2 center point (Haaland 1989), the result was shown in Table 2.

The optimization process based on experimental design that states the relationship between the three

Table 1. Variables and levels for the Box-Behnken Design method experimental design

\begin{tabular}{|c|c|c|c|c|}
\hline \multirow{2}{*}{$\begin{array}{l}\text { Independent } \\
\text { variables }\end{array}$} & \multirow{2}{*}{ Symbols } & \multicolumn{3}{|c|}{ Coded level } \\
\hline & & -1 & 0 & +1 \\
\hline Urea (\% w/w) & A & 1.5 & 3.0 & 4.5 \\
\hline $\mathrm{MgCl}_{2}(\mathrm{mM})$ & B & 1.0 & 2.5 & 4.0 \\
\hline $\mathrm{pH}$ & C & 3.5 & 4.5 & 5.5 \\
\hline
\end{tabular}

variables to enzyme activity $\left(\mathrm{E}_{\mathrm{a}}\right)$. Model equation is determined by response surface methods (RSM) and the mathematical model was presented in equation 1 .

$E_{a}=0.137+0.247 A-0.0917 B+0.00749 C-0.0158 A 2$ $+0.00741 \mathrm{~B} 2-0.0123 \mathrm{C} 2-0.0587 \mathrm{AB}+0.000967 \mathrm{AC}+$ $0.0454 \mathrm{BC}$

From the equation (1), it can be seen that there are three effects that affect in the values of Ea, namely the linear effects, quadratic effects and interaction effects.

In the linear effects, coefficient urea has the highest coefficient $(+0.247)$ followed by $\mathrm{MgCl}_{2}(-0.0197)$ and $\mathrm{pH}(+0.00749)$ while statistical result can be shown in Table 3. Therefore, effect of urea addition has high effect in increasing enzyme activity followed by $\mathrm{MgCl}_{2}$. The negative sign indicates that addition of Magnesium Chloride has high effect in decreasing enzyme activity. In quadratic effect, urea addition has the highest effect $(+0.0158)$ followed by $\mathrm{pH}(+0.0123)$ and Magnesium Chloride addition (+0.00741) while statistical result can be shown in Table 4. In interaction effects between urea concentration and $\mathrm{pH}$ shows that the coefficient has very low, therefore the equation (1) becomes equation (2):

$\mathrm{E}_{\mathrm{a}}=0.124+0.251 \mathrm{~A}-0.0917 \mathrm{~B}+0.0104 \mathrm{C}-0.0158 \mathrm{~A} 2+$ $0.00741 \mathrm{~B} 2-0.0123 \mathrm{C} 2-0.0587 \mathrm{AB}+0.0454 \mathrm{BC}$

Table 2. Experimental design and enzyme activity results using Box-Behnken Design method

\begin{tabular}{rcccc}
\hline Run & $\begin{array}{c}\mathrm{Urea} \\
(\mathrm{w} / \mathrm{w})\end{array}$ & $\begin{array}{c}\mathrm{MgCl}_{2} \\
(\mathrm{mM})\end{array}$ & $\mathrm{pH}$ & $\begin{array}{c}\text { Enzyme } \\
\text { activity } \\
(\mathrm{U} / \mathrm{g})\end{array}$ \\
\hline 1 & 1.5 & 1.0 & 4.5 & 0.2901 \\
2 & 4.5 & 1.0 & 4.5 & 0.5744 \\
3 & 1.5 & 4.0 & 4.5 & 0.4931 \\
4 & 4.5 & 4.0 & 4.5 & 0.2495 \\
5 & 1.5 & 2.5 & 3.5 & 0.3539 \\
6 & 4.5 & 2.5 & 3.5 & 0.3887 \\
7 & 1.5 & 2.5 & 5.5 & 0.3539 \\
8 & 4.5 & 2.5 & 5.5 & 0.3945 \\
9 & 3.0 & 1.0 & 3.5 & 0.5163 \\
10 & 3.0 & 4.0 & 3.5 & 0.2843 \\
11 & 3.0 & 1.0 & 5.5 & 0.4293 \\
12 & 3.0 & 4.0 & 5.5 & 0.4699 \\
13 & 3.0 & 2.5 & 4.5 & 0.4235 \\
14 & 3.0 & 2.5 & 4.5 & 0.4177 \\
\hline
\end{tabular}


Table 3. Results of the linear effect of Box-Behnken Design

\begin{tabular}{lccccccc}
\hline Source & Sum of squares & DF & Mean square & F value & F-stat with P=0,05 & Prob $>$ F & Note \\
\hline Model & 0.10981 & 9 & 0.012201 & 26.3616 & 2.48 & 0.00327 & $\mathrm{~S}$ \\
$\mathrm{~A}$ & 0.00168 & 1 & 0.001683 & 3.63636 & 2.48 & 0.129 & $\mathrm{NS}$ \\
$\mathrm{B}$ & 0.01227 & 1 & 0.012269 & 26.5091 & 2.48 & 0.00675 & $\mathrm{~S}$ \\
$\mathrm{C}$ & 0.00136 & 1 & 0.001363 & 2.94546 & 2.48 & 0.161 & $\mathrm{NS}$ \\
$\mathrm{A}^{2}$ & 0.00404 & 1 & 0.004041 & 8.73091 & 2.48 & 0.0418 & $\mathrm{~S}$ \\
$\mathrm{~B}^{2}$ & 0.00089 & 1 & 0.00089 & 1.92364 & 2.48 & 0.238 & $\mathrm{NS}$ \\
$\mathrm{C}^{2}$ & 0.00049 & 1 & 0.000486 & 1.05091 & 2.48 & 0.363 \\
AB & 0.06968 & 1 & 0.069684 & 150.564 & 2.48 & 0.000253 \\
AC & $8.41 \mathrm{E}-06$ & 1 & $8.41 \mathrm{E}-06$ & 0.01818 & 2.48 & $\mathrm{~S}$ \\
BC & 0.01859 & 1 & 0.018588 & 40.1636 & 2.48 & 0.899 \\
Residual & 0.00185 & 4 & 0.000463 & & & $\mathrm{~N}$ \\
Lack of Fit & 0.00183 & 3 & 0.000611 & 36.3333 & 2.48 & $\mathrm{~S}$ \\
Pure Error & $1.68 \mathrm{E}-05$ & 1 & $1.68 \mathrm{E}-05$ & & & & 0.121 \\
Corr. total & 0.112 & 13 & & & &
\end{tabular}

$\mathrm{DF}=$ Degree of freedom; $\mathrm{F}=\mathrm{F}$ ratio; $\mathrm{S}=$ Significant; NS = Not significant

Table 4. Results of the quadratic effect of Box-Behnken Design

\begin{tabular}{|c|c|c|c|c|c|c|c|}
\hline Source & Sum of squares & $\mathrm{DF}$ & Mean square & F value & F-stat with $\mathrm{P}=0.05$ & Prob $>$ F & Note \\
\hline Model & 0.10980 & 8 & 0.0137254 & 36.9025 & 2.48 & 0.000499 & $S$ \\
\hline A & 0.00168 & 1 & 0.0016830 & 4.52489 & 2.48 & 0.0867 & $S$ \\
\hline B & 0.01227 & 1 & 0.0122689 & 32.9864 & 2.48 & 0.00224 & S \\
\hline C & 0.00136 & 1 & 0.0013632 & 3.66516 & 2.48 & 0.114 & NS \\
\hline$A^{2}$ & 0.00404 & 1 & 0.0040408 & 10.8643 & 2.48 & 0.0216 & S \\
\hline $\mathrm{B}^{2}$ & 0.00089 & 1 & 0.0008903 & 2.39367 & 2.48 & 0.183 & NS \\
\hline$C^{2}$ & 0.00049 & 1 & 0.0004863 & 1.30769 & 2.48 & 0.305 & NS \\
\hline$A B$ & 0.06968 & 1 & 0.0696835 & 187.353 & 2.48 & $<0.0001$ & S \\
\hline $\mathrm{BC}$ & 0.01859 & 1 & 0.0185884 & 49.9774 & 2.48 & 0.000876 & S \\
\hline Residual & 0.00186 & 5 & 0.0003719 & & & & \\
\hline Lack of Fit & 0.00184 & 4 & 0.0004607 & 27.375 & 2.48 & 0.142 & \\
\hline Pure Error & $1.68 \mathrm{E}-05$ & 1 & $1.683 \mathrm{E}-05$ & & & & \\
\hline
\end{tabular}

$\mathrm{DF}=$ Degree of freedom; $\mathrm{F}=\mathrm{F}$ ratio; $\mathrm{S}=$ Significant; NS = Not significant

\subsection{Variance Analysis}

Analysis of variance was used to evaluate the accuracy and significance of the models were obtained. The goodness of fit of the model can be checked by several criteria. Table 5 shows the coefficient of $\mathrm{R}^{2}=$ 0.98 , this indicates that only $2 \%$ of total variation not explained by the model. To test the adequacy of the fitted model using static $F$. The value of $F$ is compared to the Table value $\mathrm{F}(\mathrm{p}-1, \mathrm{~N}-\mathrm{p}, \alpha)$, which is the upper $100 \alpha$ percent point of the $\mathrm{F}$ distribution with $\mathrm{p}-1$ and N-p degrees of freedom, respectively. Since the value of $\mathrm{F}$ in linear and quadratic model are 26.36 and 36.90 respectively, exceed the Table value of $F$ $=2.48$ (Table 6 ), this indicates that by the Fisher $\mathrm{F}$ test also demonstrates a high significant for the fitted regressions model.

The value of $\mathrm{F}$ quadratic effect is higher than linear effect, but the value of Prob $>F$ is smaller (Prob $>F$ value of linear and quadratic effect are 0.00327 to 0.000499 respectively), this indicated that quadratic effect model is more accurate than linear effect model. Each of the observed values (Ea)o is compared with predicted value of (Ea)p calculated from the Equation (2) can be seen in shown in Figure 1. From that figure, the observed enzyme activity is directly proportional to the predicted enzyme activity. The residual value obtained is 0.0000168 and the significant level $(\alpha)$ is 95\%, means the value "Prob> F" below 0.05 . 


\subsection{Optimization by Analyzing the Response Surface}

\subsubsection{Effect of Urea and pH to the Enzyme Activity}

It is important to investigate about urea and $\mathrm{pH}$ effect during fermentation process. For doing that, the urea concentration and $\mathrm{pH}$ were studied in the range $1.5-4.5 \% \mathrm{w} / \mathrm{w}$ and $3.5-5.5$. From the analysis of the response surface shown in Figure 2a, it can be seen that the enzyme activity increase with increasing of urea concentration and will decrease with decreasing of $\mathrm{pH}$. Optimal condition was achieved at urea concentration of $4.50 \% \mathrm{w} / \mathrm{w}, \mathrm{pH}$ of 3.50 and $\mathrm{MgCl}_{2}$ concentration of $1.00 \mathrm{mM}$ with activity of 0.630 unit/gram. While Figure $2 \mathrm{~b}$ shows that the enzyme activity increase with increasing of urea concentration and $\mathrm{pH}$. Optimal condition

Table 5. Parameter statistic for two models

\begin{tabular}{lcc}
\hline Parameter & Linear & Quadratic \\
\hline Std. Dev. & 0.02151 & 0.01929 \\
Mean & 0.40280 & 0.40280 \\
C.V. & 5.34088 & 4.78788 \\
PRESS & 0.02942 & 0.02208 \\
R-Squared & 0.98342 & 0.98335 \\
Adj. R-Squared & 0.94612 & 0.95670 \\
Pred. R-Squared & 0.73654 & 0.80226 \\
Adeq. Precision & 18.82629 & 22.13674 \\
\hline
\end{tabular}

was achieved at urea concentration of $3.00-3.75 \%$ $\mathrm{w} / \mathrm{w}, \mathrm{pH}$ of $5.00-5.50$ and $\mathrm{MgCl}_{2}$ concentration of $2.50 \mathrm{mM}$ with activity was $0.420 \mathrm{U} / \mathrm{g}$. Figure $2 c$ shows that the enzyme activity decrease with increasing of $\mathrm{pH}$ and increase with decreasing of urea concentration. Optimal condition was achieved at urea concentration of $1.50 \mathrm{w} / \mathrm{w}$, $\mathrm{pH}$ of 5.50 and $\mathrm{MgCl}_{2}$ concentration of $4.00 \mathrm{mM}$ with activity of $0.548 \mathrm{U} / \mathrm{g}$.

\subsubsection{Effect of $\mathrm{MgCl}_{2}$ and $\mathrm{pH}$ to the Enzyme Activity}

Beside correlation between urea concentration and $\mathrm{pH}$, correlation between $\mathrm{MgCl}_{2}$ concentration and $\mathrm{pH}$ also were studied in the range of $1.00-4.00 \mathrm{mM}$ and $3.5-$ 5.5. From the analysis of the response surface shown in Figure 3a, it can be seen that the enzyme activity increase with increasing of $\mathrm{MgCl}_{2}$ concentration and will decrease with increasing of $\mathrm{pH}$. Optimal condition was achieved when $\mathrm{MgCl}_{2}$ concentration was 4.00 $\mathrm{mM}, \mathrm{pH} 5.5$, and urea concentration was $1.50 \% \mathrm{w} / \mathrm{w}$, with the maximum activity is $0.549 \mathrm{U} / \mathrm{g}$. While Figure $3 \mathrm{~b}$ shows that the enzyme activity increase with decreasing of $\mathrm{MgCl}_{2}$ concentration and $\mathrm{pH}$. Optimal

Table 6. Analysis of variance activity values

\begin{tabular}{lcccccc}
\hline Source & SS & DF & MS & F & $\begin{array}{c}F \\
(005)\end{array}$ & $\begin{array}{l}\text { Prob } \\
>\text { F }\end{array}$ \\
\hline Linear & 0.1098 & 9 & 0.0122 & 26.36 & 2.48 & $\begin{array}{l}0.00 \\
\end{array}$ \\
& & & & & & 327 \\
Quadratic & 0.1098 & 8 & 0.0137 & 36.90 & 2.48 & $\begin{array}{l}0.00 \\
\end{array}$ \\
& & & & & & 0499 \\
\hline
\end{tabular}

$\overline{\mathrm{SS}}=$ sum of squares; DF = Degree of freedom; MS = Mean squares; $\mathrm{F}=\mathrm{F}$ ratio

Observed vs. Predicted values

33-level factors, 1 Blocks, 14 Runs; MS Residual=0000168

DV: Enzyme activity (U/g)

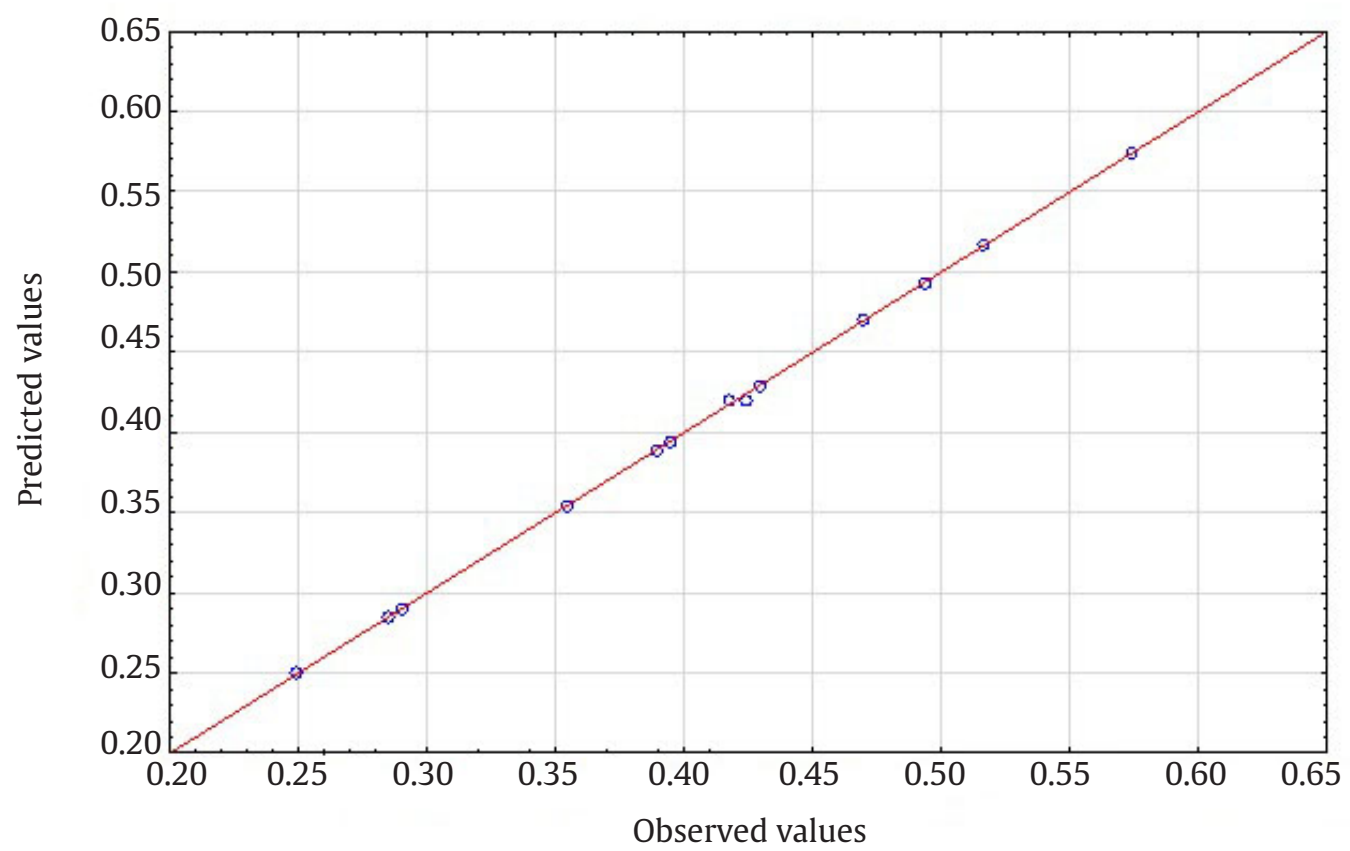

Figure 1. Correlation between observed and predicted value of cellulase enzyme activity 

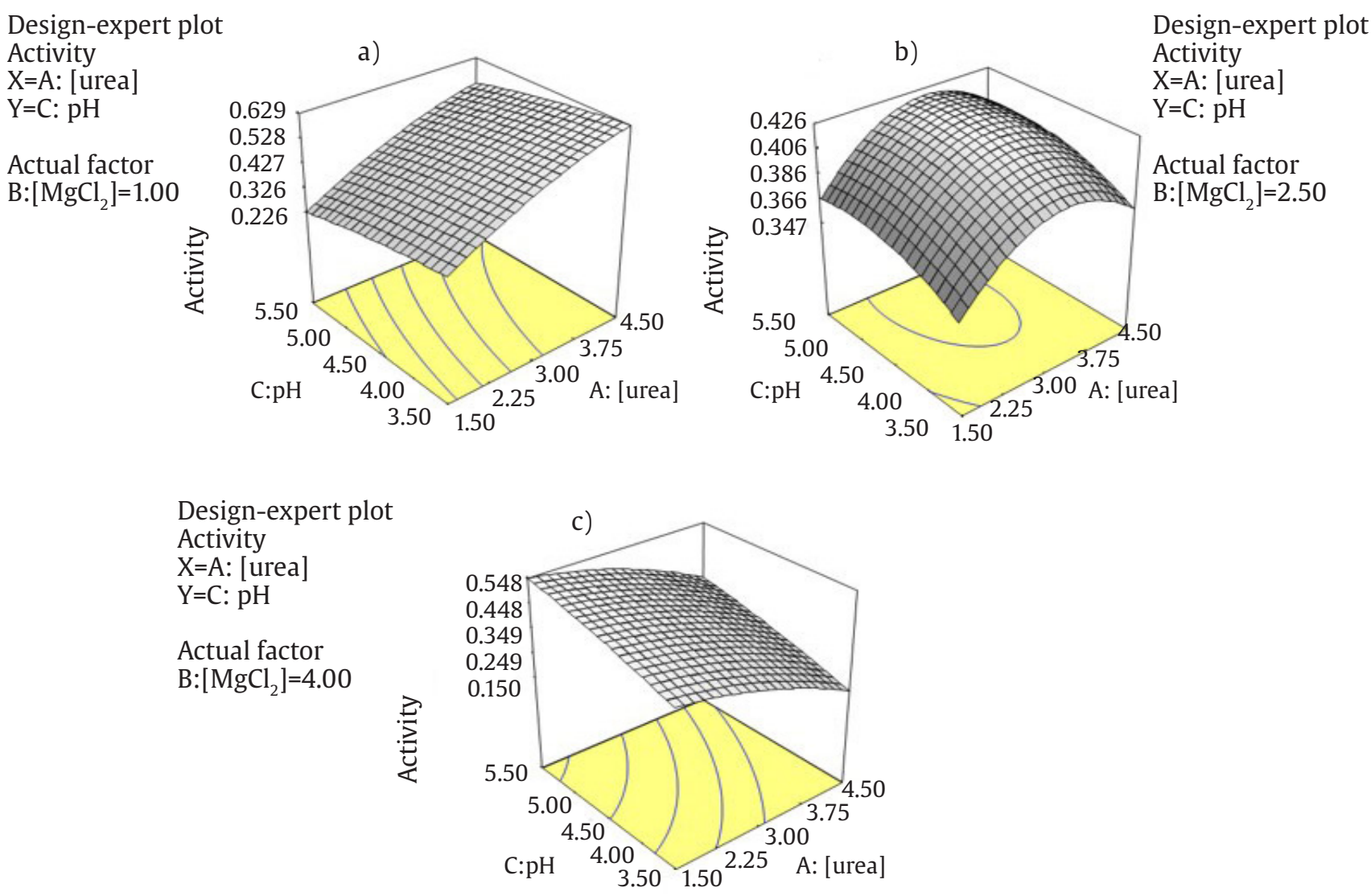

Figure 2. Predicted response as a function of urea concentration and $\mathrm{pH}$ at concentration of $\mathrm{MgCl}_{2}$ is a) $1.00 \mathrm{mM}$, b) 2.50 $\mathrm{mM}$, and c) $4.00 \mathrm{mM}$

condition was achieved at $\mathrm{MgCl}_{2}$ concentration of $1.00 \mathrm{mM}$, pH of 3.50 , and urea concentration was $3.00 \% \mathrm{w} / \mathrm{w}$ with enzyme activity was $0.515 \mathrm{U} / \mathrm{g}$. Figure $3 \mathrm{c}$ shows that the enzyme activity stagnant with increasing of $\mathrm{pH}$ and increase with decreasing of $\mathrm{MgCl}_{2}$ concentration. Optimal condition was achieved at $\mathrm{MgCl}_{2}$ concentration of $1.00 \mathrm{mM}$, pH was between $3.50-5.50$ and urea concentration of $4.00 \% \mathrm{w} / \mathrm{w}$ with activity of $0.569 \mathrm{U} / \mathrm{g}$.

\subsubsection{Effect of $\mathrm{MgCl}_{2}$ and $\mathrm{pH}$ to the Enzyme Activity}

It is also important to know the correlation between $\mathrm{MgCl}_{2}$ and urea concentration. For that, The $\mathrm{MgCl}_{2}$ and urea concentration were observed in the range of $1.00-4.00 \mathrm{mM}$ and $1.5-4.5 \% \mathrm{w} / \mathrm{w}$. From the analysis of the response surface in Figure 4a, it can be seen that the enzyme activity increase with increasing of $\mathrm{MgCl}_{2}$ and urea concentration, but by using maximum $\mathrm{MgCl}_{2}$ and urea concentration ( $4.00 \mathrm{mM}$ and $4.50 \mathrm{w} / \mathrm{w}$ respectively), the activity will decrease up to $0.350 \mathrm{U} / \mathrm{g}$. Optimal condition was achieved when $\mathrm{MgCl}_{2}$ concentration was 1.00 $\mathrm{mM}, \mathrm{pH} 3.5$, and urea concentration was $4.50 \mathrm{w} / \mathrm{w}$, with the maximum activity is $0.630 \mathrm{U} / \mathrm{g}$. While similar phenomena also were found in Figure $3 \mathrm{~b}$, which shows that the enzyme activity increase with increasing of $\mathrm{MgCl}_{2}$ and urea concentration. Similar with Figure 4a, activity will decrease up to $0.410 \mathrm{U} / \mathrm{g}$ if fermentation system used maximum $\mathrm{MgCl}_{2}$ and urea concentration together with. Optimal condition was achieved at $\mathrm{MgCl}_{2}$ concentration of $1.00 \mathrm{mM}$, $\mathrm{pH}$ of 4.50 , while urea concentration was $4.50 \% \mathrm{w} / \mathrm{w}$ with enzyme activity was $0.587 \mathrm{U} / \mathrm{g}$. Figure $4 \mathrm{c}$ shows similar phenomena with previous figure (Figure $4 a$ and b) which enzyme activity increase with increasing $\mathrm{MgCl}_{2}$ and urea concentration. Optimal condition was achieved at $\mathrm{MgCl}_{2}$ concentration of $4.00 \mathrm{mM}$, $\mathrm{pH}$ was between 5.50 and urea concentration of $1.50 \% \mathrm{w} / \mathrm{w}$ with activity of $0.548 \mathrm{U} / \mathrm{g}$. The enzyme activity will decrease up to 0.350 if $4.50 \mathrm{w} / \mathrm{w}$ urea and $4.00 \mathrm{mM}$ $\mathrm{MgCl}_{2}$ were used.

\subsubsection{Interaction Between Factors}

It is important to know the interaction between all parameter which affect to fermentation process. For doing that, interaction graph between $\mathrm{pH}$, urea concentration, and $\mathrm{MgCl}_{2}$ concentration were made. The urea factor and the $\mathrm{pH}$ factor do not interact each other. It can be shown by the two-factor interaction statistical curve as shown in Figure $5 \mathrm{a}$. It is also shown by the very small value of urea-pH coefficient, and $\mathrm{F}$ value which almost reach insignificant value as shown Table 3 in previous section. This is also supported by the RSM SmF study on fungi by Mohan et al. (2013) that showed no interaction between $\mathrm{pH}$ 
Design-expert plot

Activity

$\mathrm{X}=\mathrm{B}:\left[\mathrm{MgCl}_{2}\right]$

$\mathrm{Y}=\mathrm{C}: \mathrm{pH}$

Actual factor A: [urea $]=1.50$

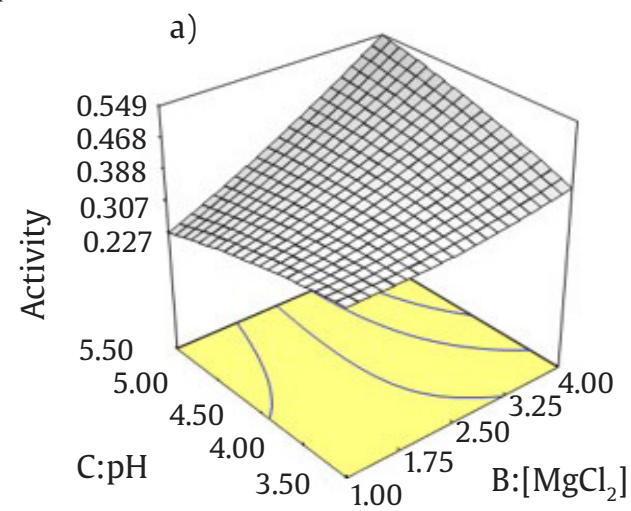

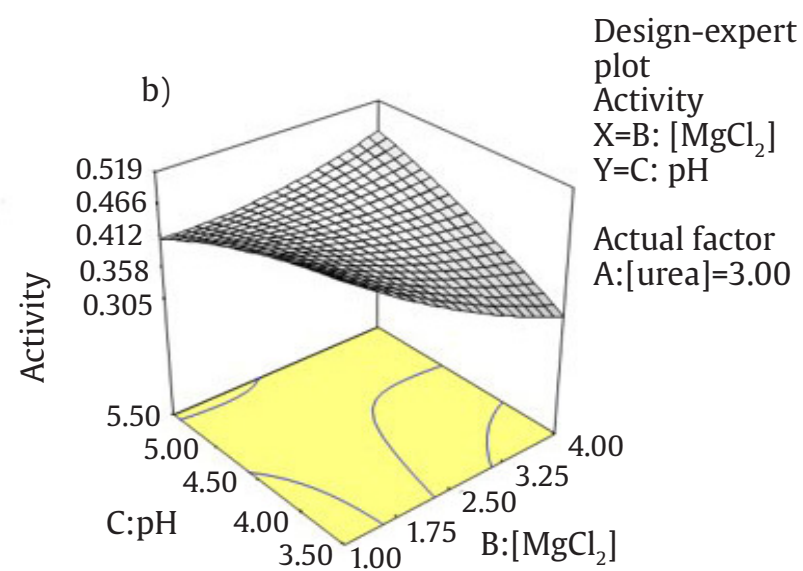

Design-expert plot

Activity

$\mathrm{X}=\mathrm{B}:\left[\mathrm{MgCl}_{2}\right]$

$\mathrm{Y}=\mathrm{C}: \mathrm{pH}$

Actual factor

A:[urea $]=4.50$

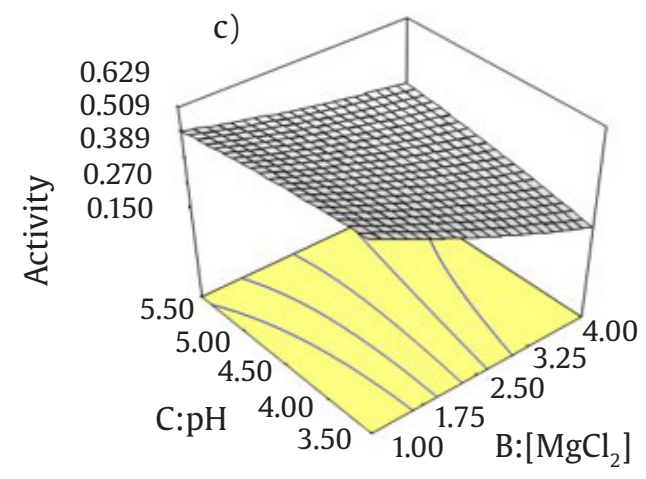

Figure 3. Predicted response as a function of $\mathrm{MgCl}_{2}$ concentration and $\mathrm{pH}$ concentration at Urea concentration is a) $1.50 \%$ $\mathrm{w} / \mathrm{w}, \mathrm{b}) 3.50 \% \mathrm{w} / \mathrm{w}$, and c) $4.00 \% \mathrm{w} / \mathrm{w}$

Design-expert plot

Activity

$\mathrm{X}=\mathrm{A}$ : [urea]

$\mathrm{Y}=\mathrm{B}:\left[\mathrm{MgCl}_{2}\right]$

Actual factor

$\mathrm{C}: \mathrm{pH}=3.50$

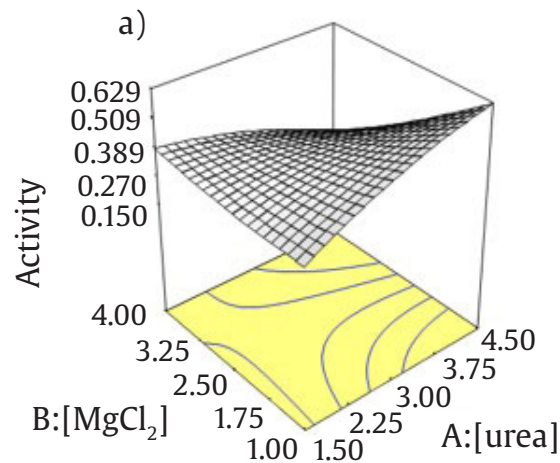

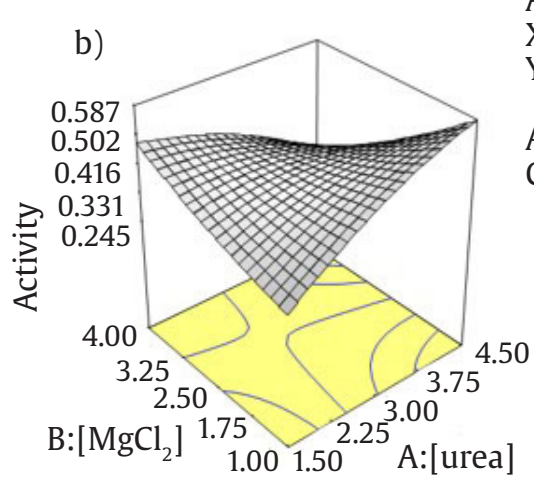

Design-expert plot Activity

$\mathrm{X}=\mathrm{A}$ : [urea]

$\mathrm{Y}=\mathrm{B}:\left[\mathrm{MgCl}_{2}\right]$

Actual factor

$\mathrm{C}: \mathrm{pH}=4.50$

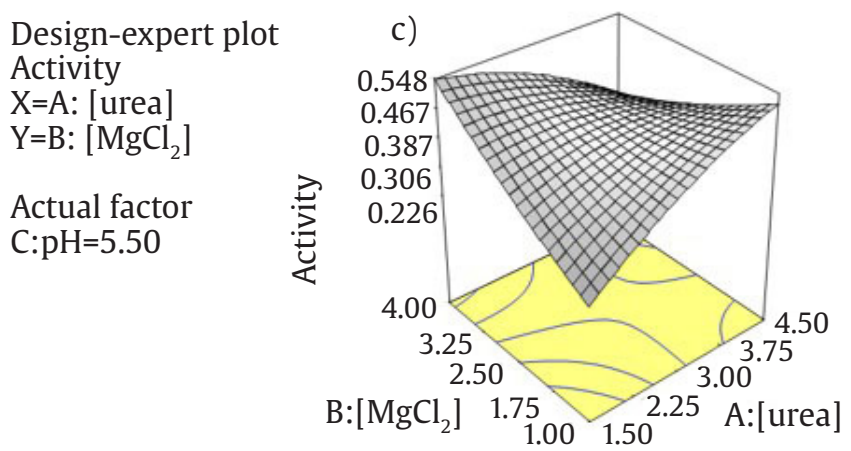

Figure 4. Predicted response as a function of urea and $\mathrm{MgCl}_{2}$ concentration at $\mathrm{pH}$ a) 3.50, b) 4.50, and c) 5.50 
and urea. Figure $5 \mathrm{~b}$ shows about interaction between $\mathrm{MgCl}_{2}$ factor and $\mathrm{pH}$ factor with an equilibrium point between two curves where the $\mathrm{MgCl}_{2}$ concentration is $2.25 \mathrm{mM}$ with $\mathrm{pH}$ between $3.50-5.50$. High value of $\mathrm{MgCl}_{2}$-pH coefficient and $\mathrm{F}$ value which reached significant value as shown Table 3 and 4 are another evidence strong relationship between $\mathrm{pH}$ and $\mathrm{MgCl}_{2}$ concentration. This phenomena about interaction between magnesium and $\mathrm{pH}$ is compatible with studies have been performed by Myers and Campbell (1985). Interaction between urea factor and $\mathrm{MgCl}_{2}$ factor can be seen in Figure $5 c$ where there is an equilibrium point between two curves with the urea concentration is around $2.50 \% \mathrm{w} / \mathrm{w}$ and $\mathrm{MgCl}_{2}$ concentration around 2.50. $\mathrm{MgCl}_{2}$-urea coefficient and $\mathrm{F}$ value are very high, higher than $\mathrm{MgCl}_{2}-\mathrm{pH}$ value, which reached significant value.

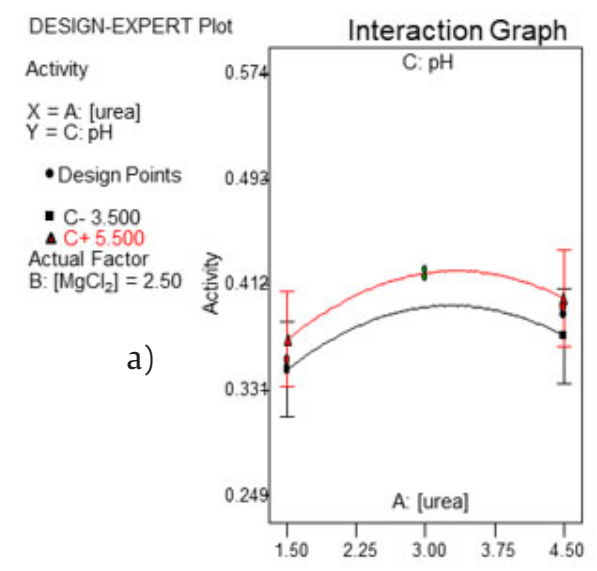

\subsection{Enzyme Activity Under Optimal Condition}

The activity model equation as a function of three factors: urea, $\mathrm{MgCl}_{2}$ and $\mathrm{pH}$ was used to determine the optimum point of the SF process. From the equation (2), the optimal process condition was obtained with numerical method to produce cellulase enzyme using A. niger ITBCC L74. The result of the experiment was observed as bell-saddle shape or a turning optimum point (Figure 2). The optimum value of cellulase activity was achieved at urea concentration of $4.5 \%$ $\mathrm{w} / \mathrm{w}, \mathrm{MgCl}_{2}$ concentration of $1 \mathrm{mM}$ and $\mathrm{pH}$ of 3.50 , with maximum activity was $0.630 \mathrm{U} / \mathrm{g}$.

It is important to compare enzyme activity between model and result from real fermentation under optimum condition. The comparison of results between model prediction and real experimental tests under optimum conditions is given in Table 7.

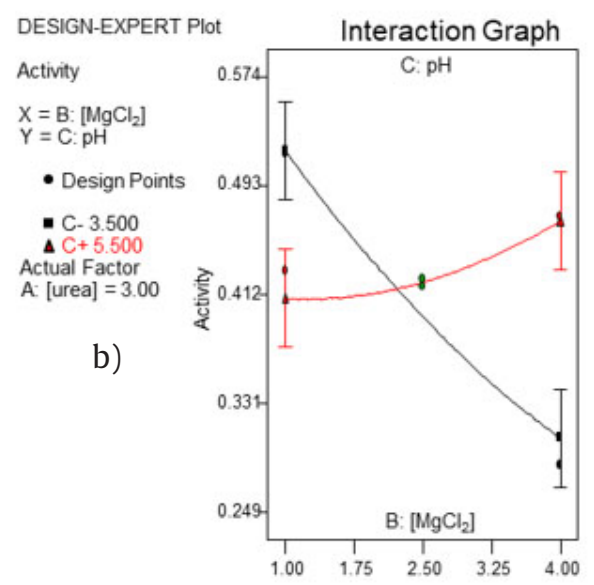

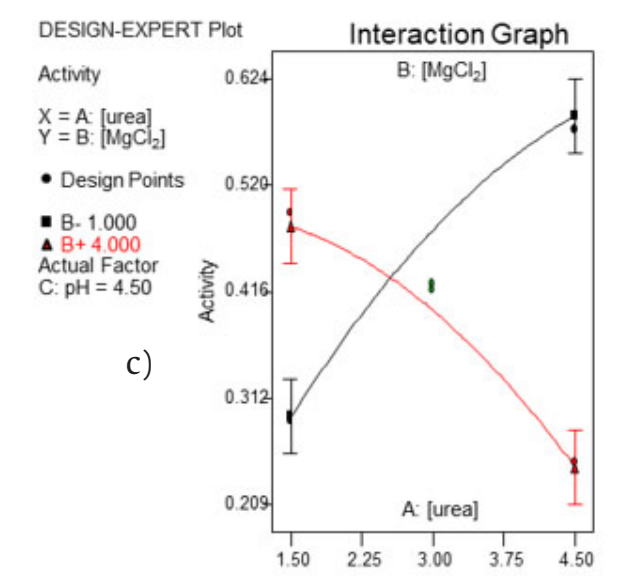

Figure 5. Interaction between factors: a) $\mathrm{pH}$ and urea concentration, b) $\mathrm{pH}$ and $\mathrm{MgCl}_{2}$ concentration, and c) urea and $\mathrm{MgCl}_{2}$ concentrations

Table 7. Enzyme activity comparison between model and real experiment under optimum condition

\begin{tabular}{ccccccc}
\hline Water (\% w/w) & Urea (\% w/w) & $\mathrm{MgCl}_{2}(\mathrm{mM})$ & $\mathrm{pH}$ & $\begin{array}{c}\text { Activity (experiment) } \\
\text { (unit/g) }\end{array}$ & $\begin{array}{c}\text { Activity (predicted) } \\
\text { (unit/g) }\end{array}$ & Error (\%) \\
\hline 80 & 4.50 & 1.00 & 3.5 & 0.511 & 0.630 & 18.95 \\
80 & 4.50 & 1.00 & 5.3 & 0.414 & 0.535 & 22.63 \\
80 & 1.50 & 4.00 & 4.5 & 0.318 & 0.480 & 33.80 \\
\hline
\end{tabular}




\section{Discussion}

In this experiment, relative high lignin content due to the reaction between bagasse and $\mathrm{NaOH}$ in pretreatment, where pretreatment process is expected will affect the lignin structure by changing its porosity (Pihlajaniemi et al. 2016). According to Galetti and Antonetti (2011), the use of alkali in lignocelluloses pretreatment can affect to degradation of ester and glycosidic chain which resulted in the degradation of lignin structure, cellulose swelling, partial hemicellulose solvation, decreased degree of cellulose crystallinity, increased internal surface area, lignin structure destruction, and bond separation structure between carbohydrates and lignin. The content of cellulose, hemicellulose, and lignin after pretreatment in this study is comparable with the experiment conducted by Rezende et al. (2011) which have done the pretreatment at $120^{\circ} \mathrm{C}$. Although the content of lignin in this study is relatively high, but the content of cellulose in the treated bagasse in this study still has the potential to be utilized as a substrate for the production of cellulase enzyme in solid state fermentation.

Nitrogen is one of the nutrients needed for microbial growth, such as A. niger (Karray et al. 2016). In the process of fermentation, nitrogen obtained from urea is decomposed by A. niger for growth process. The increasing of urea concentration makes the growth of A. niger also increase (Jasani et al. 2016), but in certain or excesses concentrations, urea can affect to decreasing in enzyme activity due to an imbalance of composition in nutrients. This imbalance of the composition may cause the metabolism of $A$. niger became disturbed and affected to its growth rate.

The interaction between magnesium and $\mathrm{pH}$ levels in this study has a surface response similar to surface response which have been done by Myers and Campbells (1985). There are some noticeable things: the increasing $\mathrm{pH}$ (above 5) and the increasing concentration of $\mathrm{MgCl}_{2}$ result in decrease of enzyme activity, whereas the decreasing $\mathrm{MgCl}_{2}$ concentration and decreasing of $\mathrm{pH}$ (below 5) cause enzyme activity increase up to a certain point. Similar with urea, magnesium is needed for $A$. niger growth and cellulase production, but it is also inhibitory at high concentrations (Mandels and Reese 1999) The same phenomenon is also shown by RSM research which have been conducted by Mohan et al. (2013).

On the other side, interaction between urea and $\mathrm{MgCl}_{2}$ is very unique. Each component can affect to increasing in enzyme activity, but on the contrary, increasing both components (urea and $\mathrm{MgCl}_{2}$ ) makes the decreasing in activity decrease. This shows that urea and $\mathrm{MgCl}_{2}$ have the same role, equally affecting the increase of activity, but raising the both concentration to the maximum level will disturb the metabolism of $A$. niger then the activity decreases. Lowering and raising one component (urea or $\mathrm{MgCl}_{2}$ concentration) becomes the best alternative way to result optimal enzyme activity.

Enzyme activity on the model is slightly higher than real experiment. Differences in enzyme activity are due to fermentation temperature that can affect growth of $A$. niger and result in decreased enzyme activity (Tucker et al. 2003; Acharya et al. 2008; Sohail et al. 2009). According to Raghuwanshi et al. (2014), $25^{\circ} \mathrm{C}$ is the best temperature in fermentation process. The difference in $5^{\circ} \mathrm{C}$ of temperature made the logarithmic phase of $A$. niger was low then may cause the lowering enzyme activity result.

Bagasse is one of good substrate for the production of cellulase under solid state fermentation by A. niger ITBCC L74. Statistical analysis demonstrated the useful way to develop optimum fermentation condition. BoxBehnkem design exhibited that urea concentration of $4.50 \% \mathrm{w} / \mathrm{w}, \mathrm{MgCl}_{2}$ concentration of $1 \mathrm{mM}$, at $\mathrm{pH} 3.50$ are the best condition for cellulase production with $A$. niger ITBCC L74 with enzyme activity is $0.630 \mathrm{U} / \mathrm{g}$. The error resulted enzyme activity between model and real experiment is $18.95 \%$. There is strong interaction between $\mathrm{MgCl}_{2}$ and $\mathrm{pH}$ factor as well as $\mathrm{MgCl}_{2}$ and urea factor, but not with urea and $\mathrm{pH}$ factor.

\section{Acknowledgements}

Abdullah and Hadiyanto would like to acknowledge the support from Diponegoro University for providing Research Professorship Program. This research was also supported by grant from PNBP Undip 2016.

\section{References}

Abdullah et al. 2016. Production of Cellulase by A. Niger and T. Reesei Under Solid State Fermentation Using Bagasse as Substrate. In: proceedings of the $3^{\text {rd }}$ Engineering Science and Technology International Conference. Padang, Indonesia.

Abubakar FA, Oloyede OB. 2013. Production and activity of cellulase from Aspergillus niger using rice bran and orange peel as substrates. Int J Sci Res Man 1:285-291.

Acharya PB et al. 2008. Optimization for cellulase production by Aspergillus niger using saw dust as substrate. Afr J Biotechnol 7:4147-4152.

Ahamed A, Vermette P. 2008. Enhanced enzyme production from mixed cultures of Trichoderma reesei RUT-C30 and Aspergillus niger LMA grown as fed batch in a stirred tank bioreactor. Biochem Eng J 42:41-46.

Behera SS, Ray RC. 2016. Solid state fermentation for production of microbial cellulases: recent advances and improvement strategies. Int J Biol Macromol 86:656-669.

Cen P, Xia L. 1999. Production of cellulase by solid-state fermentation. In: Tsao GT, editor. Recent progress in bioconversion of lignocellulosics. New York: Springer Berlin Heidelberg; pp. 69-92. 
Chandel AK et al. 2012. The realm of cellulases in biorefinery development. Crit Rev Biotechnol 32:187-202.

Chesson A. 1981. Effects of Sodium Hydroxide on Cereal Straws in Relation to the Enhanced Degradation of Structural Polysaccharides by Rumen Microorganisms. J Sci Food Agric 32:745-748.

Cunha FM et al. 2012. Sequential solid-state and submerged cultivation of Aspergillus niger on sugarcane bagasse for the production of cellulase. Bioresource Technol 112:270-274.

Daniyanto et al. 2015. Torrefaction of Indonesian Sugarcane Bagasse to Improve Bio-syngas Quality for Gasification. Energy Proc 68:157-166.

de Souza WR et al. 2011. Transcriptome analysis of Aspergillus niger grown on sugarcane bagasse. Biotechnol Biofuels 4:40.

Doran JB et al. 1994. Saccharification and fermentation of sugarcane bagasse. Biotechnol Bioeng 44:240-247.

Galetti AMR, Antonetti C. 2011. Biomass Pre-Treatment: Separation of Cellulose, Hemicellulose, Lignin. Existing Technologies and Perspectives. In: Arersta M, Dibenedetti A, and Dumeignil F, Biorefinery: from Biomass to Chemicals and Fuels, De Gruyter. Göttingen, Germany, pp. 101-117.

Ghose TK. 1987. Measurement of cellulse activities. Pure Appl Chem 59:257-268.

Gottschalk LMF et al. 2010. Cellulases, xylanases, $\beta$-glucosidase and ferulic acid esterase produced by Trichoderma and Aspergillus act synergistically in the hydrolysis of sugarcane bagasse. Biochem Eng J 51:72-78.

Haaland PD. 1989. Experimental Design in Biotechnology. New York: Marcel Dekker Inc.

Holker $U$ et al. 2004. Biotechnological advantages of laboratory-scale solid-state fermentation with fungi. Appl Microbiol Biotechnol 64:175-186.

Jasani H et al. 2016. Isolation, Optimization and Production of Cellulase by Aspergillus niger. Agricultural Waste 10:1159-1166.

Karray $\mathrm{R}$ et al. 2016. Production and characterization of enzymatic cocktail produced by Aspergillus niger using green macroalgae as nitrogen source and its application in the pre-treatment for biogas production from Ulva rigida. Bioresource Technol 216:622-628.

Knowles J et al. 1987. Cellulase families and their genes. Trends Biotechnol 5:255-261.

Krishna C. 1999. Production of bacterial cellulases by solid state bioprocessing of banana wastes. Bioresource Technol 69:231-239.

Kuhad R, Singh A. 2007. Lignocellulose biotechnology future prospects. New Delhi: IK International Publishing House Pvt Ltd.

Lynd LR et al. 2002. Microbial cellulose utilization: fundamentals and biotechnology. Microbiol Mol Biol Rev 66:506-577.

Mandels M and Reese ET. 1999. Fungal cellulases and the microbial decomposition of cellulosic fabric. J Ind Microbiol Biotechnol 22:225-240.

Mohan PR et al. 2013. Optimization of media and submerged fermentation conditions using central composite design for increased endoglucanase production by cladosporium SP. NCIM 901. Turk J Biochem 38:385395.
Mrudula S, Murugammal R. 2011. Production of cellulase by Aspergillus niger under submerged and solid-state fermentation using coir waste as a substrate. Braz J Microbiol 42:1119-1127.

Murphy TD. 1977. Design and Analysis of Industrial Experiment. Chem Eng 6:168-182.

Myers DF, Campbell RN. 1985. Lime and the Control of Crucifers: Effect of pH, Calcium, and Magnesium and Their Interaction. Phytopathology 75:670-673.

Olanbiwoninu AA, Odunfa SA. 2016. Production of Cellulase and Xylanase by Aspergillus terreus KJ829487 Using Cassava Peels as Substrates. Adv Microbiol 6:502.

Omojasola PF et al. 2008. Cellulase Production by Some Fungi Cultured on Pineapple Waste. Nat Sci 6:64-79.

Omojasola PF, Jilani OP. 2008. Cellulase production by Trichoderma longi, Aspergillus niger and Saccharomyces cerevisae cultured on waste materials from orange. Pakistan J Biol Sci 11:2382-2388.

Pandey A et al. 2000. New developments in solid state fermentation: I-bioprocesses and products. Process Biochem 35:1153-1169.

Pihlajaniemi V et al. 2016. Weighing the factors behind enzymatic hydrolyzability of pretreated lignocellulose. Green Chem 18:1295-1305.

Raghuwanshi S et al. 2014. Bioprocessing of enhanced cellulase production from a mutant of Trichoderma asperellum RCK2011 and its application in hydrolysis of cellulose. Fuel 124:183-189.

Raza F et al. 2011. Solid State Fermentation for the Production of ??-Glucosidase by Co-Culture of Aspergillus niger and A. oryzae. Pak J Bot 43:75-83.

Rezende CM et al. 2011. Chemical and Morphological Characterization of Sugarcane Bagasse Submitted to a Delignification Process for Enhanced Enzymatic Digestibility. Biotechnol Biofuels 4:54.

Rodríguez CS, Sanroman M. 2005. Application of solid-state fermentation to ligninolytic enzyme production. Biochem Eng J 22:211-219.

Rosés RP, Guerra NP. 2009. Optimization of amylase production by Aspergillus niger in solid-state fermentation using sugarcane bagasse as solid support material. World J Microbiol Biotechnol 25:1929-1939.

Sarkar N, Aikat K. 2012. Alkali Pretreatment of Rice Straw and Enhanced Cellulase Production by a Locally Isolated Fungus Aspergillus fumigatus NITDGPKA3. J Microbiol Biotechnol Res 2:717-726.

Sen R. 1997. Response Surface Optimization of the critical Media Components for the Production of Surfactin. Enzyme Microb Technol 68:263-270.

Sindhu R et al. 2016. Biological pretreatment of lignocellulosic biomass-An overview. Bioresource Technol 199:7682.

Singhania RR et al. 2009. Recent advances in solid-state fermentation. Biochem Eng J 44:13-18.

Singhania RR et al. 2010. Advancement and comparative profiles in the production technologies using solidstate and submerged fermentation for microbial cellulases. Enzyme Microb Technol 46:541-549.

Sohail CMR et al. 2009. Cellulase production from Aspergillus niger MS82: effect of temperature and $\mathrm{pH}$. New Biotechnol 25:437-441. 
Tabka MG et al. 2006. Enzymatic saccharification of wheat straw for bioethanol production by a combined cellulase xylanase and feruloyl esterase treatment. Enzyme Microb Technol 39:897-902.

Tucker MP et al. 2003. Effects of temperature and moisture on dilute-acid steam explosion pretreatment of corn stover, and cellulase enzyme digestibility. Appl Biochem Biotechnol 105:165-177.
Vazquez M, Martin AM. 1998. Optimization of Phaffia rhodozymactic Continuous Culture Through Response Surface Methodology. Biotechnol Bioeng 57:314-320.

$\mathrm{Vu} \mathrm{VH}$ et al. 2011. Improvement of Fungal Cellulase Production by Mutation and Optimization of Solid State Fermentation. Mycobiology 39:20-25.

Yoon LW et al. 2014. Fungal solid-state fermentation and various methods of enhancement in cellulase production. Biomass Bioenergy 67:319-338. 